\title{
Nitric Oxide Acts as a Postsynaptic Signaling Molecule in Calcium/ Calmodulin-Induced Synaptic Potentiation in Hippocampal CA1 Pyramidal Neurons
}

\author{
Gladys Y. Ko and Paul T. Kelly \\ Department of Neurobiology and Anatomy, University of Texas Medical School at Houston, Houston, Texas 77225
}

Postsynaptic injection of $\mathrm{Ca}^{2+} /$ calmodulin $\left(\mathrm{Ca}^{2+} / \mathrm{CaM}\right)$ into hippocampal CA1 pyramidal neurons induces synaptic potentiation, which can occlude tetanus-induced potentiation (Wang and Kelly, 1995). Because $\mathrm{Ca}^{2+} / \mathrm{CaM}$ activates the major forms of nitric oxide synthase (NOS) to produce nitric oxide (NO), NO may play a role during $\mathrm{Ca}^{2+} / \mathrm{CaM}$-induced potentiation. Here we show that extracellular application of the NOS inhibitor $N^{G}$-nitro-L-arginine methyl ester (L-NAME) or postsynaptic co-injection of L-NAME with $\mathrm{Ca}^{2+} / \mathrm{CaM}$ blocked $\mathrm{Ca}^{2+} / \mathrm{CaM}$-induced synaptic potentiation. Thus, $\mathrm{NO}$ is necessary for $\mathrm{Ca}^{2+} / \mathrm{CaM}$-induced synaptic potentiation. In contrast, extracellular perfusion of membraneimpermeable NO scavengers $N$-methyl-D-glucamine dithiocarbamate/ferrous sulfate mixture (MGD-Fe) or 2-(4-carboxyphenyl)4,4,5,5-tetramethylimidazoline-1-oxyl-3-oxide (carboxy-PTIO) did

The role of nitric oxide (NO) as a retrograde messenger in hippocampal long-term potentiation (LTP) has been suggested by many studies (O’Dell et al., 1991; Schuman and Madison, 1991, 1994a,b; Haley et al., 1992; Bredt and Snyder, 1994; Garthwaite and Boulton, 1995; Arancio et al., 1996). Extracellular application of NO donors facilitates LTP induction (Malen and Chapman, 1997), whereas extracellular administration of nitric oxide synthase (NOS) inhibitors or NO scavengers or postsynaptic injection of NOS inhibitors attenuates and/or blocks LTP induced by tetanus or pairing protocols (Haley et al., 1992; Williams et al., 1993a; Schuman and Madison, 1994a; Arancio et al., 1996) (but see Chetkovitch et al., 1993; Cummings et al., 1994). Two major forms of constitutive NOS in brain are neuronal NOS and endothelial NOS (nNOS and eNOS, respectively) (Bredt and Snyder, 1994), and both are present in the hippocampus (Dinerman et al., 1994; Doyle and Slater, 1997; Eliasson et al., 1997). Mutant mice lacking nNOS and eNOS display significantly attenuated hippocampal LTP (Son et al., 1996).

Previous results have shown that postsynaptic injection of

Received March 10, 1999; revised May 26, 1999; accepted May 27, 1999.

This work was supported by National Institutes of Health Grant NS 32470 and National Institutes of Health Training Grant NS 07373. We thank Dr. Yashige Kotake (Oklahoma Medical Research Foundation, Oklahoma City, OK) for MGD and $\mathrm{FeSO}_{4}$ and Drs. Jaroslaw Aronowski (University of Texas-Houston Medical School, Houston, TX) and Owen Griffith (Medical College of Wisconsin, Milwaukee, WI) for fruitful comments and discussion. We also thank Drs. Y. Kotake and Takaaki Akaike (Kumamoto University School of Medicine, Kumamoto, Japan) for making available unpublished results.

Correspondence should be addressed to Paul T. Kelly, Department of Molecular Biosciences, 7042 Haworth Hall, The University of Kansas, Lawrence, KS 660452106. E-mail:ptkelly@eagle.cc.ukans.edu

Dr. Ko's present address: Department of Biology and Biochemistry, Science and Research 2 Building, University of Houston, Houston, TX 77204.

Copyright (C) 1999 Society for Neuroscience $0270-6474 / 99 / 196784-11 \$ 05.00 / 0$ not attenuate $\mathrm{Ca}^{2+} / \mathrm{CaM}$-induced synaptic potentiation, even though MGD-Fe or carboxy-PTIO blocked tetanus-induced synaptic potentiation. This result indicates that $\mathrm{NO}$ is not a retrograde messenger in $\mathrm{Ca}^{2+} / \mathrm{CaM}$-induced synaptic potentiation. However, postsynaptic co-injection of carboxy-PTIO with $\mathrm{Ca}^{2+} / \mathrm{CaM}$ blocked $\mathrm{Ca}^{2+} / \mathrm{CaM}$-induced potentiation. Postsynaptic injection of carboxy-PTIO alone blocked tetanus-induced synaptic potentiation without affecting basal synaptic transmission. Our results suggest that NO works as a postsynaptic (intracellular) messenger during $\mathrm{Ca}^{2+} / \mathrm{CaM}$-induced synaptic potentiation.

Key words: nitric oxide; calmodulin; hippocampus; synaptic plasticity; synaptic potentiation; nitric oxide scavengers; nitric oxide synthase inhibitors

$\mathrm{Ca}^{2+} /$ calmodulin $\left(\mathrm{Ca}^{2+} / \mathrm{CaM}\right)$ induces synaptic potentiation in hippocampal CA1 neurons (Wang and Kelly, 1995). $\mathrm{Ca}^{2+} / \mathrm{CaM}-$ induced synaptic potentiation is similar to tetanus-induced LTP because it is blocked by co-injecting a calmodulin binding peptide or pseudosubstrate inhibitors of $\mathrm{Ca}^{2+} / \mathrm{CaM}$-dependent kinase II (CaMKII) or protein kinase C (PKC) (Wang and Kelly, 1995). Tetanus-induced LTP and $\mathrm{Ca}^{2+} / \mathrm{CaM}$-induced synaptic potentiation reciprocally occlude each other, so their underlying mechanisms may be similar (Wang and Kelly, 1995). Because mechanisms responsible for tetanus-induced LTP expression are believed to be in part presynaptic (Malinow and Tsien, 1990a; Bolshakov and Siegelbaum, 1995), it is important to determine whether $\mathrm{Ca}^{2+} / \mathrm{CaM}$-induced synaptic potentiation involves a presynaptic mechanisms(s), particularly because the latter is induced by an apparently restricted postsynaptic manipulation. For example, postsynaptic injection of $\mathrm{Ca}^{2+} / \mathrm{CaM}$ could activate $n / e N O S$ and elevate NO in neurons (Bredt and Snyder, 1990; Bredt et al., 1992; Brenman et al., 1996), and NO could act as a retrograde messenger during $\mathrm{Ca}^{2+} / \mathrm{CaM}$-induced synaptic potentiation. Alternatively, $\mathrm{NO}$ could contribute to $\mathrm{Ca}^{2+} / \mathrm{CaM}$-induced synaptic potentiation by acting locally in postsynaptic neurons to directly nitrosylate and/or oxidize proteins (Lei et al., 1992; Lipton et al., 1993, 1996; Li et al., 1999) or indirectly via the activation of guanylyl cyclase/cyclic GMP-dependent protein kinase and/or ADP-ribosyl transferase pathways (Boulton et al., 1995; Schuman et al., 1994; Zhou et al., 1994a,b; Kleppisch et al., 1999).

We examined the role of NOS and NO in synaptic potentiation induced by postsynaptic injection of $\mathrm{Ca}^{2+} / \mathrm{CaM}$. We also investigated whether NO acted as a retrograde messenger and/or a postsynaptic signaling molecule in $\mathrm{Ca}^{2+} / \mathrm{CaM}$-induced synaptic potentiation. Tetanus-induced synaptic potentiation was monitored as an index for the effectiveness of an NOS inhibitor or NO 
scavengers. Here we show that postsynaptic NO is involved in $\mathrm{Ca}^{2+} / \mathrm{CaM}$-induced potentiation but not as a retrograde messenger. On the other hand, we observed that tetanus-induced potentiation appears to require NO-dependent retrograde signaling, consistent with previous observations (O'Dell et al., 1991; Schuman and Madison, 1991, 1994a; Haley et al., 1992; Arancio et al., 1996; Malen and Chapman, 1997).

\section{MATERIALS AND METHODS}

Male and female Sprague Dawley rats (35-55 days old; from Harlan Sprague Dawley, Indianapolis, IN; and Charles River, Wilmington, MA) were used in this study. Animals were group-housed and maintained in a temperature-controlled environment with a $12 \mathrm{hr}$ light/dark cycle. Transverse hippocampal slices $(400 \mu \mathrm{m})$ were prepared using a McIlwain tissue chopper with ice-cold modified artificial CSF (ACSF). Slices were incubated at $25^{\circ} \mathrm{C}$ in ACSF over $1 \mathrm{hr}$ and transferred to a submersion chamber $\left(31.8 \pm 0.5^{\circ} \mathrm{C} ; 2.5-3 \mathrm{ml} / \mathrm{min}\right.$ perfusion rate) for electrophysiological recordings. ACSF contained (in $\mathrm{mM}$ ): $124 \mathrm{NaCl}, 3 \mathrm{KCl}, 1.3$ $\mathrm{NaH}_{2} \mathrm{PO}_{4}, 26 \mathrm{NaHCO}_{3}, 2.0 \mathrm{MgCl}_{2}, 2.4 \mathrm{CaCl}_{2}, 10$ glucose, and 10 HEPES, $\mathrm{pH}$ 7.3. A modified ACSF used for slice preparation contained $4.0 \mathrm{mM} \mathrm{MgCl}_{2}$ and $1.2 \mathrm{mM} \mathrm{CaCl}{ }_{2}$. All media were bubbled with a $95 \% \mathrm{O}_{2}-5 \% \mathrm{CO}_{2}$ mixture. Experiments were conducted in "standard" ACSF containing bicuculline $(5 \mu \mathrm{M})$, and the concentration of $\mathrm{MgCl}_{2}$ was $2.4 \mathrm{~mm}$. Isolated CA1 slices were made by cutting presynaptic axons in stratum radiatum but not in oriens/alveus at the CA1-CA3 border. Under these conditions, seizure activity was never observed during basal synaptic transmission. Complex waveforms only occurred after tetanic stimulation in some experiments. In designated experiments, the perfusion medium also contained $100 \mu \mathrm{M} N^{\mathrm{G}}$-nitro-L-arginine methyl ester (L-NAME), a mixture of $150 \mu \mathrm{M} \mathrm{N}$-methyl-D-glucamine dithiocarbamate and $75 \mu \mathrm{M} \mathrm{FeSO}_{4} \cdot 7 \mathrm{H}_{2} \mathrm{O}(150 / 75 \mu \mathrm{M}$ MGD-Fe), or $30 \mu \mathrm{M}$ 2-(4carboxyphenyl)-4,4,5,5-tetramethylimidazoline-1-oxyl-3-oxide (carboxyPTIO). Constant flow rates were maintained throughout experiments especially during media exchanges.

Glass microelectrodes $(60-85 \mathrm{M} \Omega$ ) filled with $2 \mathrm{M}$ potassium acetate (KAc), carboxy-PTIO in $2 \mathrm{M} \mathrm{KAc}, \mathrm{Ca}^{2+} / \mathrm{CaM} / \mathrm{KAc}$, or $\mathrm{Ca}^{2+} / \mathrm{CaM} /$ $\mathrm{KAc}$ plus various agents [i.e., L-NAME, $N^{\mathrm{G}}$-nitro-D-arginine methyl ester (D-NAME), or carboxy-PTIO] were used for intracellular recordings in CA1 pyramidal neurons in bridge mode. $\mathrm{Ca}^{2+} / \mathrm{CaM} / \mathrm{KAc}$ was prepared from $\mathrm{CaCl}_{2}, \mathrm{CaM}$, and $\mathrm{KAc}$ stocks to obtain final concentrations of 80 and $20 \mu \mathrm{M}$ and $2 \mathrm{M}$, respectively. Input resistance was estimated by injecting negative current $(0.12 \mathrm{nA})$ for $50 \mathrm{msec}$ before each evoked stimulus and monitored throughout recordings. Results were only collected from neurons in which stable recordings were obtained within the initial 2-5 min after impalement with resting membrane potentials between -65 and $-73 \mathrm{mV}$, and in which input resistance changed $<20 \%$ throughout the entire experiment. Extracellular field EPSPs were recorded using glass pipettes (containing $0.9 \% \mathrm{NaCl}$ ) placed below the intracellular recording site (halfway between stratum pyramidale and the hippocampal fissure). One bipolar tungsten stimulating electrode $(\sim 12$ $\mathrm{M} \Omega$ ) was placed in CA1 stratum radiatum for orthodromic stimulation of Schaffer collateral/commissural fibers. Test stimuli were given at $0.05 \mathrm{~Hz}$, and stimulus intensity was adjusted to evoke about one-half to threefifths of maximal synaptic responses. Tetanic stimulation was delivered at $100 \mathrm{~Hz}$ (five trains of 25 pulses at $5 \mathrm{sec}$ intervals) and the same stimulus intensity used to evoke baseline responses. Intracellular and extracellular recordings, data acquisition, and analysis were performed using an AxoClamp 2B amplifier with Axoscope and Clampfit softwares (Axon Instruments). Initial baseline values were averaged from EPSP slopes obtained during the first 1-2 min after intracellular recordings stabilized and defined as $100 \%$. Values of tetanus- or $\mathrm{Ca}^{2+} / \mathrm{CaM}$-induced synaptic potentiation, or different drug treatments, were obtained from data points averaged over a $2 \mathrm{~min}$ period at the time indicated (e.g., $45 \mathrm{~min}$ after beginning intracellular injection). Student's $t$ tests were used for comparisons within the same experimental groups at different times (paired $t$ test) and for comparisons between different groups at comparable experimental times (nonpaired $t$ test). Values were expressed as mean \pm SEM; significant differences were determined at the $p<0.05$ level.

Bicuculline methbromide was obtained from Research Biochemicals (Natick, MA), CaM from Calbiochem (La Jolla, CA), L-NAME and D-NAME from Sigma (St. Louis, MO), carboxy-PTIO from Cayman (Ann Arbor, MI); MGD and $\mathrm{FeSO}_{4} \cdot 7 \mathrm{H}_{2} \mathrm{O}$ were gifts from Dr. Yashige
Kotake (Oklahoma Medical Research Foundation, Oklahoma City, OK); chemicals for ACSF were from Fisher Scientific (Fair Lawn, NJ).

\section{RESULTS \\ Postsynaptic injection of $\mathrm{Ca}^{2+} / \mathrm{CaM}$ induces synaptic potentiation}

Intracellular recordings using sharp microelectrodes with simultaneous extracellular field recordings were used to monitor synaptic transmission of hippocampal CA1 neurons. Postsynaptic injections of $\mathrm{Ca}^{2+} / \mathrm{CaM}$ (80 and $20 \mu \mathrm{M}$, respectively) into CA1 pyramidal neurons by passive diffusion from microelectrodes induced a gradual increase in the initial slopes of EPSPs (Fig. $1 A$ ). Initial baseline values were averaged from six consecutive EPSPs during the first 1-2 min after intracellular recordings stabilized and defined as $100 \%$. Figure $1 A$ shows that postsynaptic injection of $\mathrm{Ca}^{2+} / \mathrm{CaM}$ into CA1 pyramidal neurons for 45 min induced significant synaptic potentiation of EPSP slopes (184 $\pm 19 \% ; n=5 ; 45$ min after beginning intracellular injections) compared with initial baseline values $(p<0.05)$. These results are consistent with previous studies showing that postsynaptic injection of $\mathrm{Ca}^{2+} / \mathrm{CaM}$ enhanced excitatory synaptic transmission (Wang and Kelly, 1995). Simultaneous extracellular field recordings showed a stable baseline during the pretetanus period $(105 \pm 6 \% ; n=5 ; 45$ min after beginning intracellular injections; Fig. $1 B$ ), whereas intracellular injections displayed $\mathrm{Ca}^{2+} / \mathrm{CaM}$ induced potentiation. The magnitude of $\mathrm{Ca}^{2+} / \mathrm{CaM}$-induced potentiation decreased after $100 \mathrm{~Hz}$ tetanic stimulation (25 pulses, five trains at $5 \mathrm{sec}$ intervals). This depotentiation was previously observed; however, the underlying mechanism is not known (Wang and Kelly, 1995). In contrast, field recordings showed significant potentiation induced by tetanus $(155 \pm 15 \%$ at $30 \mathrm{~min}$ after tetanus; $n=5$, Fig. $1 B ; 148 \pm 21 \%$ at 60 min after tetanus; results not shown). A control group was included, in which microelectrodes were filled only with 2 m KAc. After recording stable baselines for $20 \mathrm{~min}$, tetanus was delivered, which induced significant synaptic potentiation in both intracellular $(198 \pm 16 \%$ at 30 min after tetanus; $n=4$; Fig. $1 C ; p<0.05)$ and field EPSP slopes $(167 \pm 11 \%$ at 30 min after tetanus; $n=4$; Fig. $1 D ; p<$ $0.05)$ compared with pretetanus baseline values.

\section{Extracellular NOS/NO modulators block tetanus- induced synaptic potentiation}

Because our ultimate goal was to determine whether NO signaling pathways contribute to $\mathrm{Ca}^{2+} / \mathrm{CaM}$-induced synaptic potentiation, we needed an independent measurement of the efficacy of NO modulators in our experiments. Previous studies indicated that extracellular application of NOS inhibitors or NO scavengers blocked tetanus-induced potentiation in hippocampal CA1 area (Schuman and Madison, 1991, 1994a; Haley et al., 1992). To investigate whether NOS/NO modulators would affect basal synaptic transmission or block tetanus-induced potentiation, the following experiments were conducted using extracellular field recordings. Stable baselines (field EPSPs) were recorded for at least 20-30 min, and then extracellular perfusions of an NOS inhibitor or NO scavenger were initiated. We used recently developed NO scavengers MGD and carboxy-PTIO instead of hemoglobin. Extracellular perfusion of hemoglobin can depolarize CA1 neurons and suppress EPSPs and IPSPs in the presence of the NOS inhibitor $N$ - $\omega$-nitro-L-arginine, suggesting that hemoglobin has other effects that are independent of its NO scavenging activity (Yip et al., 1996). MGD mixed with reduced iron $\left(\mathrm{Fe}^{2+}\right)$ forms a stable and water-soluble complex (MGD-Fe; Komarov et al., 

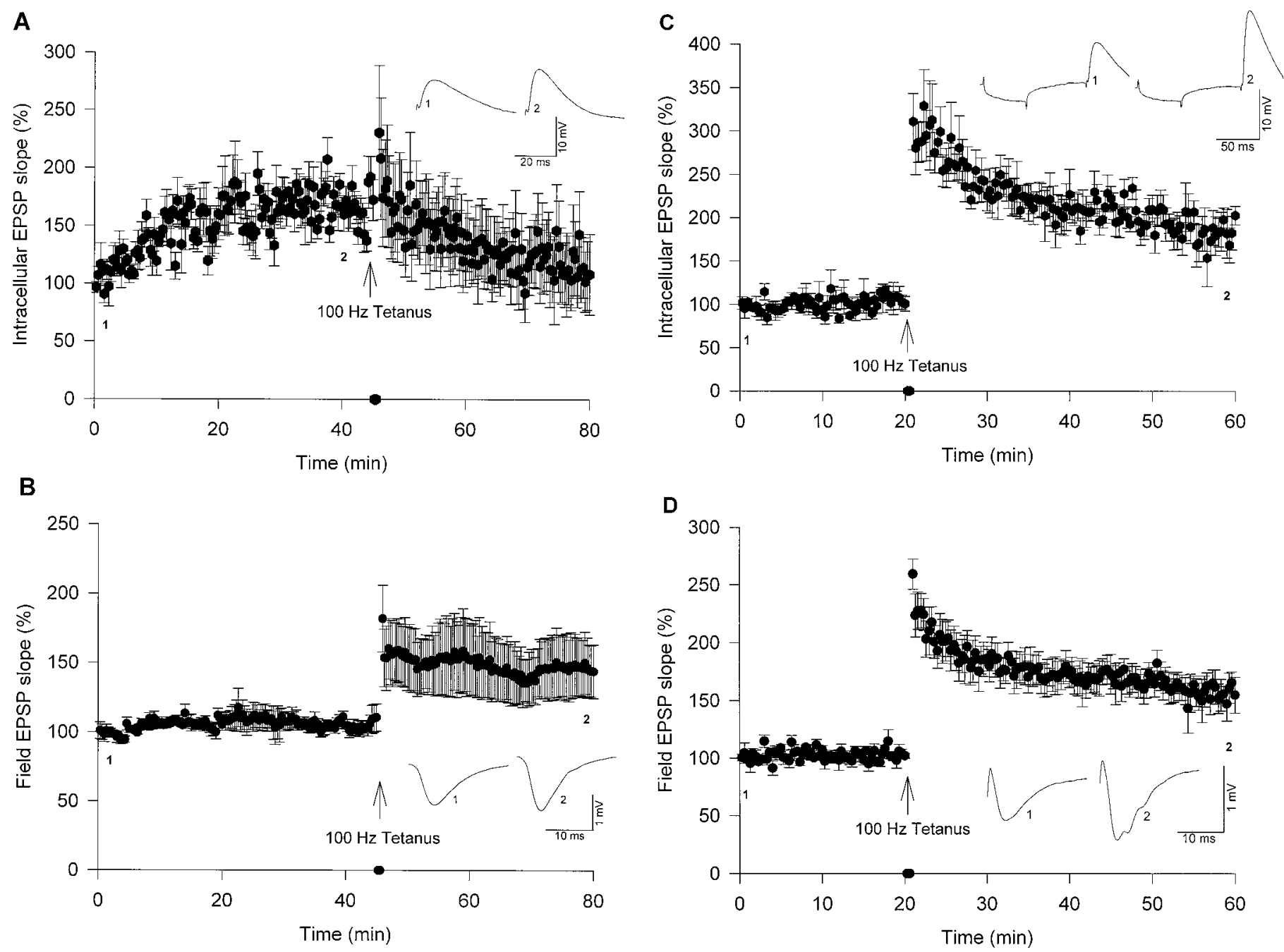

Figure 1. Postsynaptic injection of $\mathrm{Ca}^{2+} / \mathrm{CaM}$ induces synaptic potentiation. $A, B, \mathrm{Ca}^{2+} / \mathrm{CaM}$ was injected for $45 \mathrm{~min}$, and then a $100 \mathrm{~Hz}$ tetanus was delivered. $A$, Synaptic potentiation induced by postsynaptic $\mathrm{Ca}^{2+} / \mathrm{CaM}$ injections $(n=5)$. $B$, Simultaneous field recordings displayed stable baseline EPSPs followed by tetanus-induced synaptic potentiation $(n=5)$. $C, D$, Tetanic stimulation under control conditions induced synaptic potentiation. $C$, Intracellular recordings, microelectrodes filled with 2 м KAc $(n=4)$. $D$, Simultaneous field recordings of control group $(n=4)$.

1993), which is cell membrane-impermeable (Y. Kotake, personal communication) and has been used for in vivo spin trapping of NO in mice (Lai and Komarov, 1994; Komarov and Lai, 1995; Kotake et al., 1995). MGD-Fe has also been used to scavenge NO produced by cells in culture (Kotake, 1996; Kotake et al., 1996) or in vitro cardiovascular preparations (Pieper and Lai, 1996). Perfusion of freshly mixed MGD and $\mathrm{FeSO}_{4}$ (i.e., MGD-Fe) at different concentrations was tested (data not shown). MGD-Fe mixtures of $100 / 25,100 / 37.5$, and $100 / 50 \mu \mathrm{M}$ did not block tetanusinduced potentiation; however, MGD-Fe at 150/75 $\mu \mathrm{M}$ successfully blocked tetanus-induced potentiation without affecting basal synaptic transmission (see below).

We also tested carboxy-PTIO, which is water-soluble and scavenges NO without affecting NOS activity (Az-ma et al., 1994; Maeda et al., 1994; Yoshida et al., 1994; Amano and Noda, 1995; Hogg et al., 1995a,b). Preliminary results in cultured cells indicate that carboxy-PTIO is cell membrane-impermeable (T. Akaike, personal communication). Extracellular perfusions of carboxyPTIO at $5,7.5,10$, or $15 \mu \mathrm{M}$ failed to block tetanus-induced potentiation (data not shown), whereas $30 \mu \mathrm{M}$ carboxy-PTIO reliably blocked tetanus-induced potentiation without affecting basal synaptic transmission (see below).

The concentration chosen for the NOS inhibitor L-NAME was based on previous studies in which L-NAME attenuated tetanusLTP under certain conditions (Williams et al., 1993a; Nicolarakis et al., 1994). L-NAME (100 $\mu \mathrm{M}, n=10)$ was perfused for $60 \mathrm{~min}$, and NO scavenger MGD-Fe $(150 / 75 \mu \mathrm{M}, n=7)$ or carboxy-PTIO (30 $\mu \mathrm{M}, n=7$ ) was perfused for $30 \mathrm{~min}$ before tetanus (Fig. $2 A$ ). Drug containing ACSFs were switched to standard ACSF 5 min after tetanus. L-NAME, MGD-Fe, or carboxy-PTIO was applied separately. Both MGD-Fe and carboxy-PTIO significantly blocked tetanus-induced potentiation $(111 \pm 4$ and $113 \pm 13 \%$, respectively, at $30 \mathrm{~min}$ after tetanus; Fig. $2 A, B)$ compared with controls (standard ACSF, $189 \pm 12 \%$, at 30 min after tetanus; $n=11 ; p<0.05)$. After perfusion of L-NAME for $60 \mathrm{~min}$, there was a slight increase in field EPSP slopes $(108 \pm 5 \% ; n=10)$, which was not significantly different from the pretreatment baseline (104 $\pm 4 \%$ immediately before L-NAME perfusion). L-NAME attenuated tetanus-induced potentiation at $30 \mathrm{~min}$ after tetanus $(146 \pm 10 \% ; n=10)$ compared with controls $(p<0.05)$ 

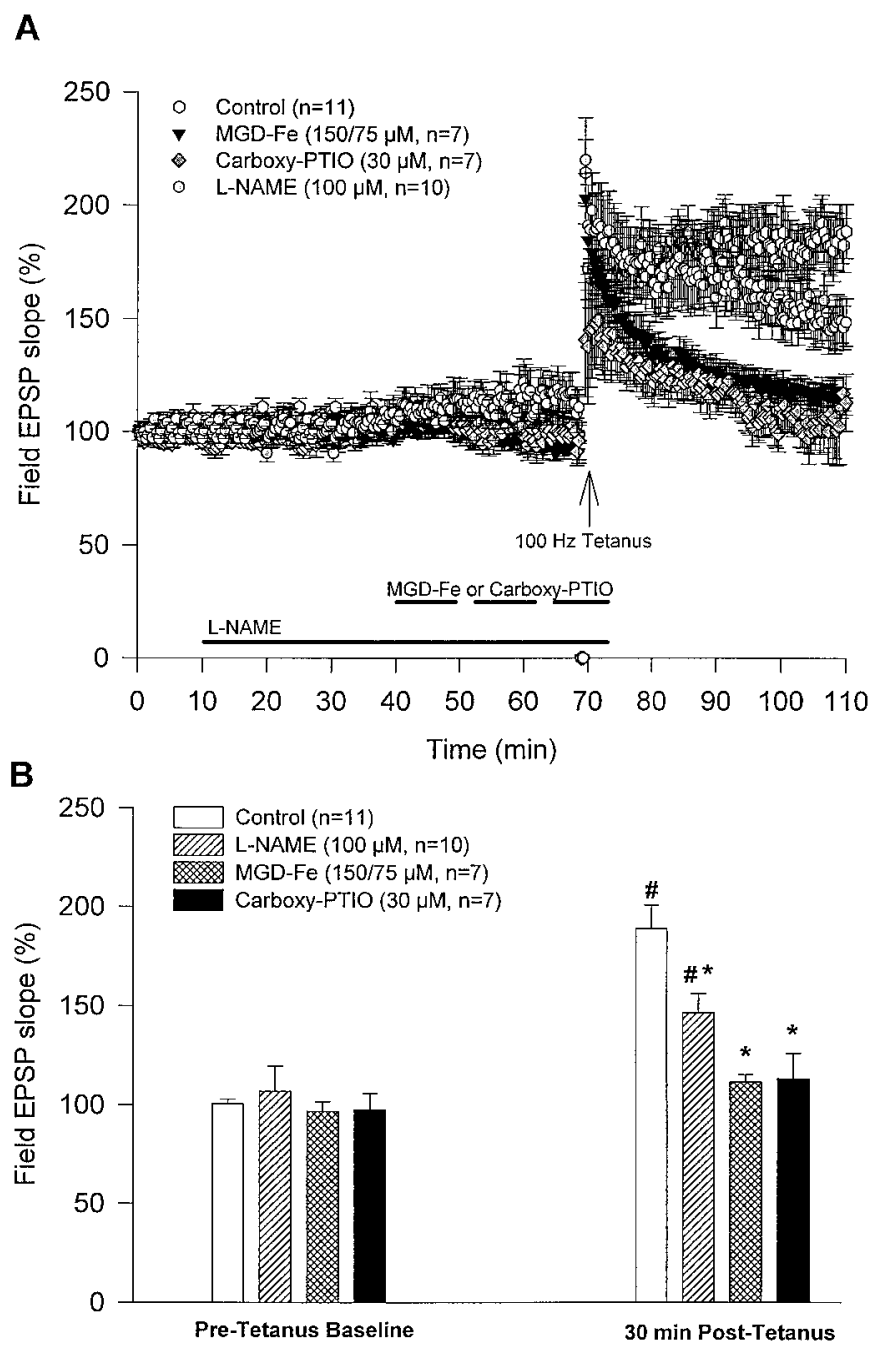

Figure 2. Extracellular perfusion of an NOS inhibitor (L-NAME) or NO scavengers (MGD-Fe and carboxy-PTIO) attenuate tetanus-induced synaptic potentiation. $A$, After stable baseline recordings, media containing the NOS inhibitor or NO scavengers were perfused for different durations (see Results) followed by tetanic stimulation. Five minutes after tetaus, perfusion media were switched to standard ACSF. Control slices $(n=11)$ were perfused with standard ACSF. $B$, L-NAME $(100 \mu \mathrm{M} ; n=10)$, MGD-Fe (150/75 $\mu \mathrm{M} ; n=7)$ or carboxy-PTIO (30 $\mu \mathrm{M} ; n=7)$ did not significantly affect basal synaptic transmission compared with controls. Thirty minutes after tetanus, synaptic potentiation was induced in both control and L-NAME groups, which was significantly different from the pretetanus baseline within the same group $(\# p<0.05)$. However, tetanusinduced potentiation in L-NAME, MGD-Fe, and carboxy-PTIO groups at 30 min after tetanus was significantly attenuated compared with controls $\left({ }^{*} p<0.05\right)$.

and virtually blocked tetanus-induced potentiation when examined at 60 min after tetanus $(113 \pm 6 \%$; no significant difference from the pretetanus baseline).

\section{NOS inhibitor blocks $\mathrm{Ca}^{2+} / \mathrm{CaM}$-induced potentiation}

To examine the possibility that NOS activity might contribute to synaptic potentiation induced by postsynaptic injection of $\mathrm{Ca}^{2+}$ / CaM, hippocampal slices were preincubated with L-NAME (100 $\mu \mathrm{M}$ ) for $1 \mathrm{hr}$ before being transferred to the recording chamber. Stable field recordings (field EPSPs) were established for at least $20 \mathrm{~min}$, and then postsynaptic injections of $\mathrm{Ca}^{2+} / \mathrm{CaM}$ with microelectrodes were performed. L-NAME $(100 \mu \mathrm{M})$ was also
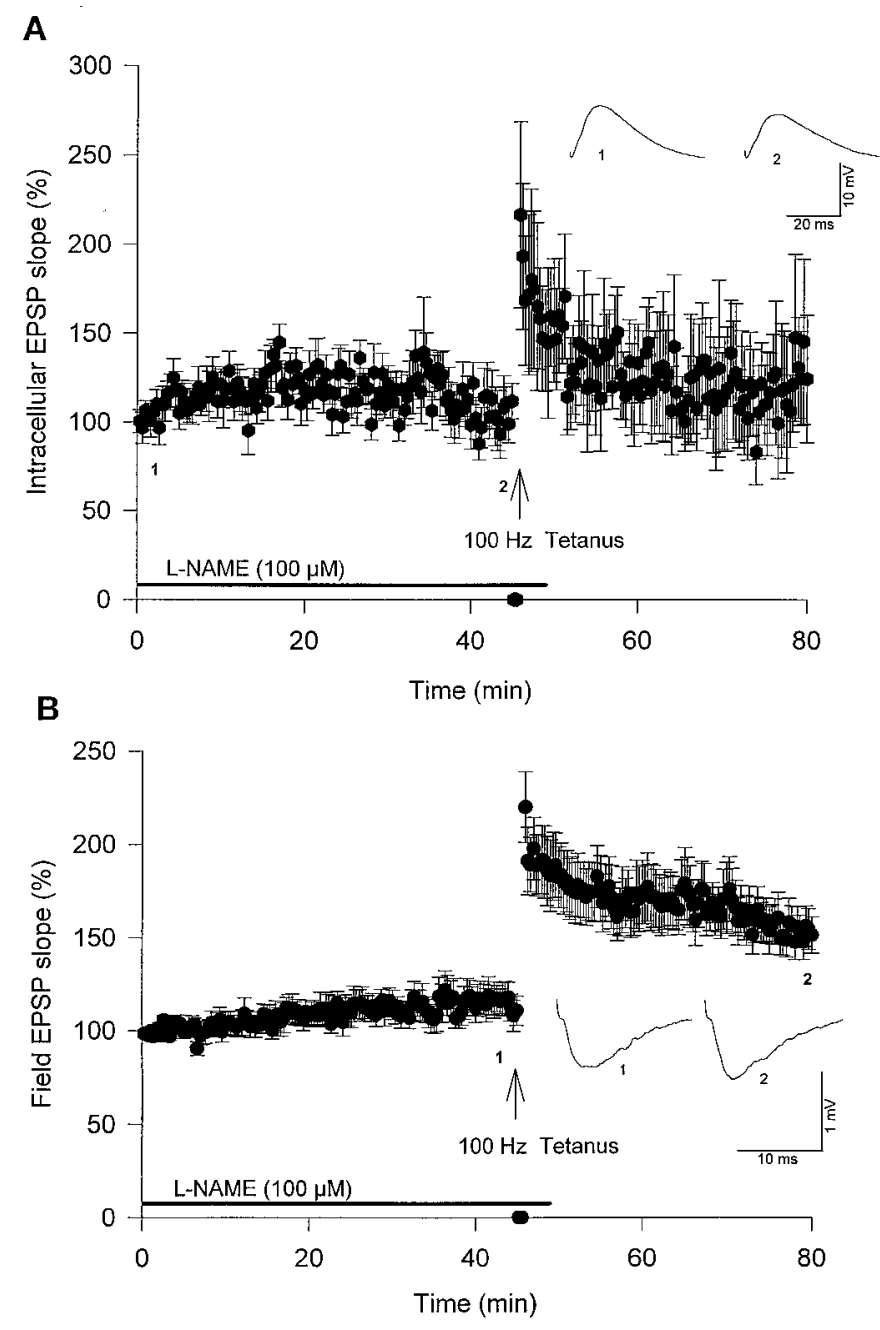

Figure 3. Extracellular L-NAME blocks $\mathrm{Ca}^{2+} / \mathrm{CaM}$-induced synaptic potentiation $(n=10)$. Slices were pretreated with L-NAME $(100 \mu \mathrm{M})$ for $\geq 1 \mathrm{hr}$ before beginning postsynaptic injections of $\mathrm{Ca}^{2+} / \mathrm{CaM}$. Five minutes after tetanus, slices were perfused with standard ACSF without L-NAME. $A$, Synaptic potentiation induced by postsynaptic $\mathrm{Ca}^{2+} / \mathrm{CaM}$ injections was blocked by L-NAME. $B$, Simultaneous field recordings showed that tetanus-induced synaptic potentiation was attenuated by L-NAME.

present in the perfusate until $5 \mathrm{~min}$ after tetanus. Under these conditions, L-NAME significantly blocked $\mathrm{Ca}^{2+} / \mathrm{CaM}$-induced synaptic potentiation $(104 \pm 13 \% ; n=10,45$ min after beginning injections; Fig. $3 A$ ) compared with $\mathrm{Ca}^{2+} / \mathrm{CaM}$ alone $(184 \pm 19 \%$; $n=5$, 45 min after beginning injections; Fig. $1 A ; p<0.05)$. L-NAME also blocked tetanus-induced synaptic potentiation in $\mathrm{Ca}^{2+} / \mathrm{CaM}$-injected neurons $(114 \pm 29 \% ; n=10,30 \mathrm{~min}$ after tetanus; Fig. $3 A$ ) compared with controls (at 30 min after tetanus; Fig. $1 C ; p<0.05)$. In addition, L-NAME attenuated tetanusinduced potentiation of field EPSPs at $30 \mathrm{~min}$ after tetanus $(138 \pm 8 \% ; n=10$; Fig. $3 B)$ and blocked potentiation at $60 \mathrm{~min}$ after tetanus $(115 \pm 8 \% ; n=10$; results not shown) compared with field EPSPs recorded during $\mathrm{Ca}^{2+} / \mathrm{CaM}$ injections alone $(148 \pm 21 \% ; n=5,60 \mathrm{~min}$ after tetanus; results not shown; $p<0.05)$.

To investigate whether postsynaptic NOS activity contributes to $\mathrm{Ca}^{2+} / \mathrm{CaM}$-induced synaptic potentiation, L-NAME was coinjected with $\mathrm{Ca}^{2+} / \mathrm{CaM}$ into CA1 neurons. The addition of 100 

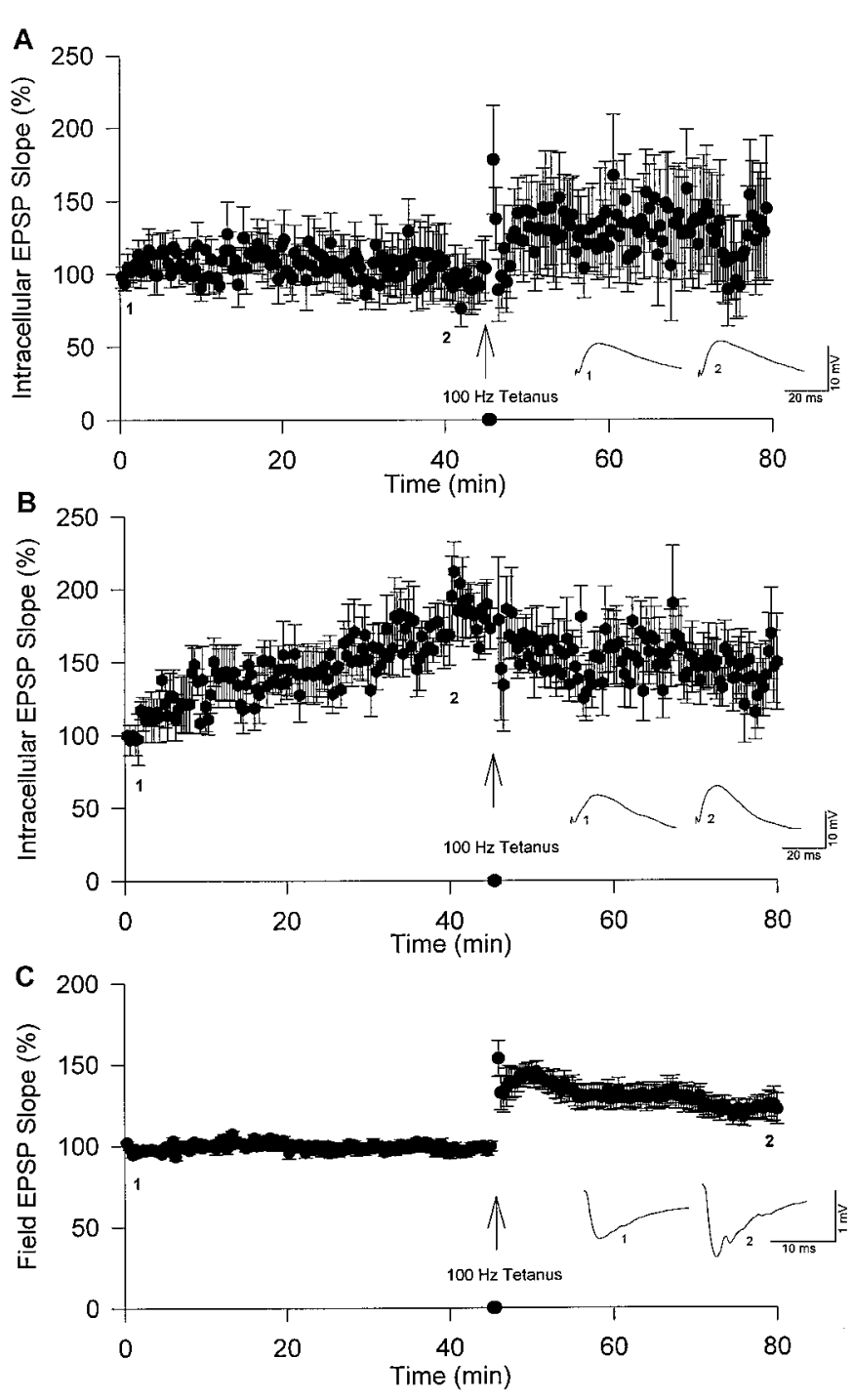

Figure 4. Postsynaptic co-injection of L-NAME, but not D-NAME, blocks $\mathrm{Ca}^{2+} / \mathrm{CaM}$-induced synaptic potentiation. $A$, Synaptic potentiation induced by postsynaptic co-injections of $\mathrm{Ca}^{2+} / \mathrm{CaM}$ and L-NAME $(100 \mathrm{mM} ; n=8)$. $B$, Synaptic potentiation induced by postsynaptic co-injection of $\mathrm{Ca}^{2+} / \mathrm{CaM}$ and D-NAME (67 or $100 \mathrm{mM} ; n=6$ ). $C$, Simultaneous field recordings showed synaptic potentiation induced by tetanus (L-NAME and D-NAME groups combined; $n=14$ ).

mM L-NAME to $\mathrm{Ca}^{2+} / \mathrm{CaM}(80 / 20 \mu \mathrm{M})$ in microelectrodes blocked $\mathrm{Ca}^{2+} / \mathrm{CaM}$-induced potentiation $(98 \pm 17 \% ; n=8,45$ min after beginning injections; Fig. $4 A$ ) compared with $\mathrm{Ca}^{2+} /$ CaM injections alone (184 $\pm 19 \% ; n=5,45$ min after beginning injections; Fig. $1 A ; p<0.05)$. Co-injection of L-NAME and $\mathrm{Ca}^{2+} / \mathrm{CaM}$ also blocked tetanus-induced synaptic potentiation $(113 \pm 30 \% ; n=5,30$ min after tetanus; Fig. $4 A)$ compared with neurons injected with $2 \mathrm{M} \mathrm{KAc}$ alone (30 min after tetanus; Fig. $1 \mathrm{C} ; p<0.05)$. In contrast, co-injection of $\mathrm{Ca}^{2+} / \mathrm{CaM}$ and D-NAME (67 or $100 \mathrm{~mm})$, a stereoisomer much less potent than L-NAME, did not block $\mathrm{Ca}^{2+} / \mathrm{CaM}$-induced potentiation (178 \pm $16 \% ; n=6,45 \mathrm{~min}$ after beginning injections; Fig. $4 B$ ). Tetanic stimulation of neurons co-injected with D-NAME and $\mathrm{Ca}^{2+} /$ $\mathrm{CaM}$ resulted in depotentiation (Fig. $4 B$ ), which was consistent with previous results (Fig. $1 A$ ). Simultaneous extracellular field recordings in the same slices showed stable baselines for $45 \mathrm{~min}$
[99 $\pm 4 \% ; n=14$ (L-NAME and D-NAME groups combined); Fig. $4 C$ ], and tetanus induced significant potentiation at $30 \mathrm{~min}$ $(135 \pm 7 \% ; n=14$; Fig. $4 C)$ or 60 min after tetanus $(133 \pm 10 \%$; $n=14$; results not shown) compared with pretetanus baseline $(p<0.05)$. Although L-NAME is a membrane-permeable NOS inhibitor, these results suggest that postsynaptic NOS activity is important for $\mathrm{Ca}^{2+} / \mathrm{CaM}$-induced synaptic potentiation.

\section{Extracellular NO scavengers block tetanus-induced potentiation but not $\mathbf{C a}^{2+} / \mathrm{CaM}$-induced potentiation} Since previous studies indicated that NO acted as a retrograde messenger at hippocampal synapses (O'Dell et al., 1991; Schuman and Madison, 1991, 1994a; Haley et al., 1992; Garthwaite and Boulton, 1995; Arancio et al., 1996), and our recent results showed the importance of NOS activity in $\mathrm{Ca}^{2+} / \mathrm{CaM}$-induced potentiation (see above; Ko and Kelly, 1998), we examined the role of $\mathrm{NO}$ as a retrograde messenger in $\mathrm{Ca}^{2+} / \mathrm{CaM}$-induced potentiation using extracellular applications of MGD-Fe or carboxy-PTIO to scavenge NO. Hippocampal slices were pretreated in the recording chamber with either MGD-Fe (150/75 $\mu \mathrm{M} ; n=7)$ for $60 \mathrm{~min}$ or carboxy-PTIO $(30 \mu \mathrm{M} ; n=4)$ for $30 \mathrm{~min}$ before obtaining extracellular recordings. Thirty minutes after establishing stable extracellular field recordings, postsynaptic injections of $\mathrm{Ca}^{2+} / \mathrm{CaM}$ were initiated. MGD-Fe or carboxy-PTIO was present in the perfusate until $5 \mathrm{~min}$ after tetanus. Both MGD-Fe and carboxy-PTIO effectively blocked tetanus-induced synaptic potentiation (109 \pm 7 and $115 \pm 14 \%$, respectively, 30 min after tetanus; Fig. 5B,D) compared with field recordings of $\mathrm{Ca}^{2+} / \mathrm{CaM}$ injections alone (30 min after tetanus; Fig. $1 B ; p<$ $0.05)$. In contrast, extracellular perfusion of MGD-Fe or carboxyPTIO did not block synaptic potentiation induced by postsynaptic injections of $\mathrm{Ca}^{2+} / \mathrm{CaM}(170 \pm 23$ and $201 \pm 44 \%$, respectively, 45 min after beginning injections; Fig. $5 A, C)$. Tetanic stimulation of $\mathrm{Ca}^{2+} / \mathrm{CaM}$-injected neurons treated with $\mathrm{MGD}-\mathrm{Fe}$ or carboxy-PTIO resulted in depotentiation (Fig. 5A,C), which was consistent with previous results (Figs. $1 A, 4 B$ ). These results suggest that NO does not act as a retrograde messenger in $\mathrm{Ca}^{2+} / \mathrm{CaM}$-induced synaptic potentiation, but NO still works as a retrograde messenger in tetanus-induced potentiation, which is consistent with previous reports (O’Dell et al., 1991; Schuman and Madison, 1991, 1994a; Haley et al., 1992; Arancio et al., 1996; Malen and Chapman, 1997).

\section{Postsynaptic injection of NO scavenger blocks $\mathrm{Ca}^{2+} / \mathrm{CaM}$-induced potentiation}

We have shown that NOS activity is essential for synaptic potentiation induced by postsynaptic injections of $\mathrm{Ca}^{2+} / \mathrm{CaM}$ (Figs. $3 A, 4 A$ ). On the other hand, extracellular administration of NO scavengers MGD-Fe or carboxy-PTIO did not block $\mathrm{Ca}^{2+} / \mathrm{CaM}$ induced potentiation (Fig. 5A,C). Taken together, these results suggest that NO produced by postsynaptic NOS, which is important for $\mathrm{Ca}^{2+} / \mathrm{CaM}$-induced potentiation, may not function as a retrograde messenger but acts directly at postsynaptic sites. To test this hypothesis, we co-injected $\mathrm{Ca}^{2+} / \mathrm{CaM}$ and carboxyPTIO (30 mM) into postsynaptic CA1 neurons. Co-injections of carboxy-PTIO significantly blocked $\mathrm{Ca}^{2+} / \mathrm{CaM}$-induced potentiation $(120 \pm 10 \% ; n=6,45 \mathrm{~min}$ after beginning injections; Fig. $6 A$ ) compared with $\mathrm{Ca}^{2+} / \mathrm{CaM}$ injections alone (45 min after beginning injections; Fig. $1 A ; p<0.05)$. Postsynaptic injections of carboxy-PTIO alone (30 mm; Fig. $6 C$ ) did not affect basal synaptic transmission $(114 \pm 16 \% ; n=4,45$ min after beginning injections) but did block tetanus-induced potentiation $(87 \pm 10 \%$ 

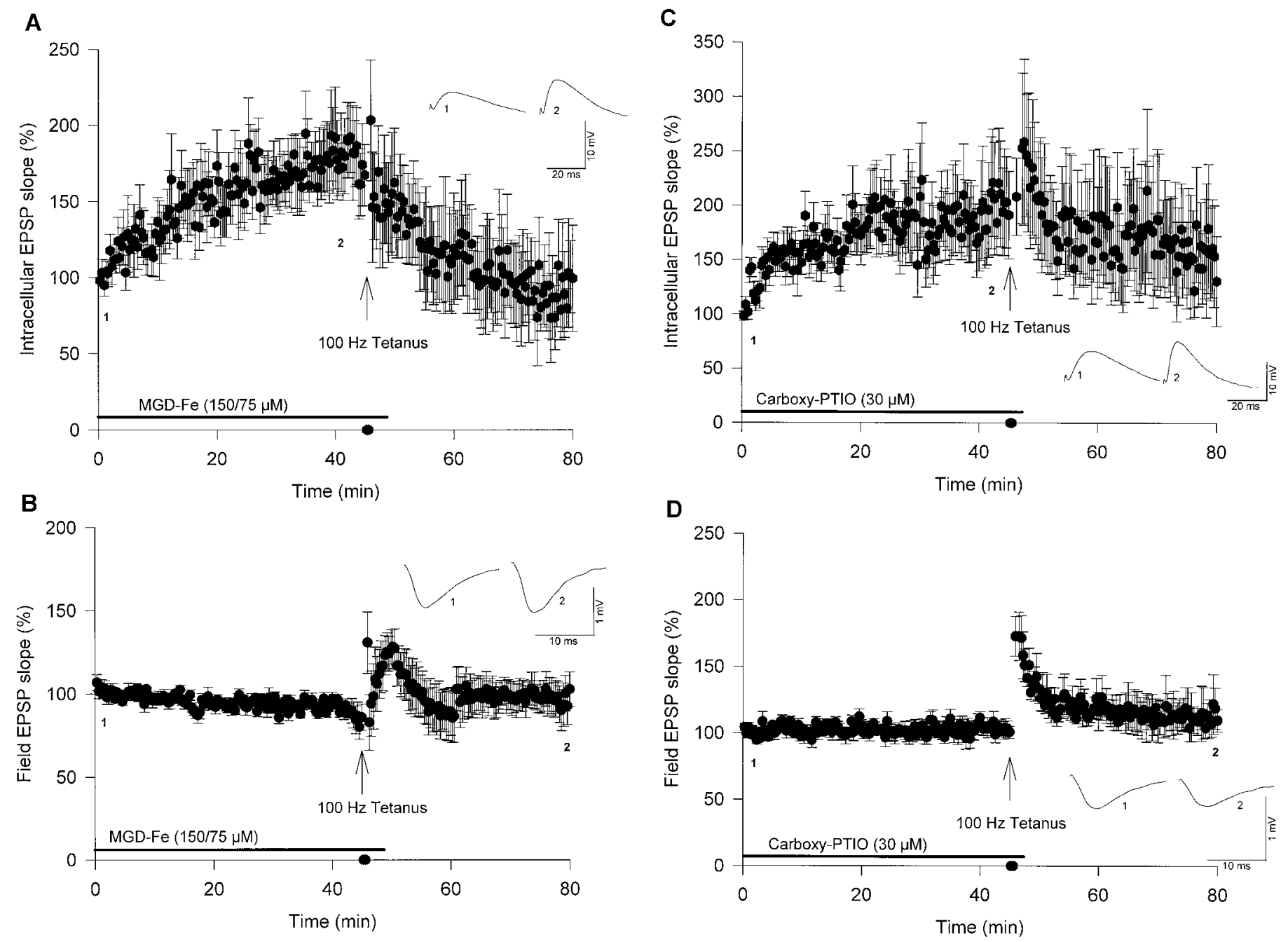

Figure 5. Extracellular applications of NO scavengers MGD-Fe and carboxy-PTIO block tetanus- but not $\mathrm{Ca}^{2+} / \mathrm{CaM}^{-i n d u c e d}$ synaptic potentiation. $A$, $B$, Slices were pretreated with MGD-Fe $(150 / 75 \mu \mathrm{M})$ for 30-60 min before postsynaptic injections of $\mathrm{Ca}^{2+} / \mathrm{CaM}(n=7)$. Five minutes after tetanus the medium was switched to standard ACSF. $A$, Synaptic potentiation induced by postsynaptic $\mathrm{Ca}^{2+} / \mathrm{CaM}$ injections was not blocked by MGD-Fe. $B$, MGD-Fe blocked tetanus-induced synaptic potentiation in field recordings. $C$, $D$, Slices were pretreated with carboxy-PTIO (30 $\mu \mathrm{M})$ for $30-60$ min before postsynaptic injections of $\mathrm{Ca}^{2+} / \mathrm{CaM}(n=4)$. Three minutes after tetanus the medium was switched to standard ACSF. $C$, Synaptic potentiation induced by postsynaptic $\mathrm{Ca}^{2+} / \mathrm{CaM}$ injections was not blocked by carboxy-PTIO. $D$, Carboxy-PTIO blocked tetanus-induced synaptic potentiation in field recordings.

at 30 min after tetanus). Simultaneous field recordings in these experiments showed stable baselines and tetanus-induced potentiation at $30 \mathrm{~min}$ after tetanus (145 \pm 10 and $154 \pm 14 \%$, respectively; Fig. $6 B, D$ ) compared with their baseline values obtained 1-2 min before tetanus (both $p<0.05$ ). These results indicate that $\mathrm{NO}$ acts as a postsynaptic and intracellular messenger during $\mathrm{Ca}^{2+} / \mathrm{CaM}$-induced synaptic potentiation but not as a retrograde messenger. On the other hand, NO functions, at least in part, as a retrograde messenger in tetanus-induced synaptic potentiation.

\section{DISCUSSION}

Our results show that postsynaptic injection of $\mathrm{Ca}^{2+} / \mathrm{CaM}$ into hippocampal CA1 pyramidal neurons induces synaptic potentiation, which is consistent with previous reports (Wang and Kelly, $1995,1996)$. In the nervous system, $\mathrm{Ca}^{2+} / \mathrm{CaM}$ regulates many enzymes and channels (Rhoads and Friedberg, 1997), including adenylyl cyclase (Sunahara et al., 1996; Smit and Iyengar, 1998), $\mathrm{Ca}^{2+} / \mathrm{CaM}$-dependent protein kinases (Braun and Shulman,
1995), phosphodiesterases (Sharma, 1995; Zhao et al., 1997), NOS (Bredt and Snyder, 1994; Lee and Stull, 1998), calcineurin (Guerini, 1997; Klee et al., 1998), NMDA receptors (Ehlers et al., 1996; Hisatsune et al., 1997; Zhang et al., 1998), ryanodine receptors (Ikemoto et al., 1995; Guerrini et al., 1995), and cyclic nucleotide-gated channels (Molday, 1996; Zagotta and Siegelbaum, 1996). Many of these signaling molecules, including CaMKII and NOS, are believed to be involved in LTP (Malenka et al., 1989; Ocorr and Schulman, 1991; O'Dell et al., 1991; Schuman and Madison, 1991, 1994a,b; Lledo et al., 1995).

Postsynaptic injection of $\mathrm{Ca}^{2+} / \mathrm{CaM}$ significantly decreases paired-pulse facilitation (PPF) (Wang and Kelly, 1996). Mechanisms responsible for changing PPF are believed to be presynaptic (Magleby, 1987; Zucker, 1989; but see Wang and Kelly, 1996, 1997b); therefore, changes in PPF are often interpreted to be attributable to presynaptic changes in transmitter release (Creager et al., 1980; Muller and Lynch, 1989; Manabe et al., 1993; Schulz et al., 1994). Postsynaptic injections of $\mathrm{Ca}^{2+} / \mathrm{CaM}$ could 

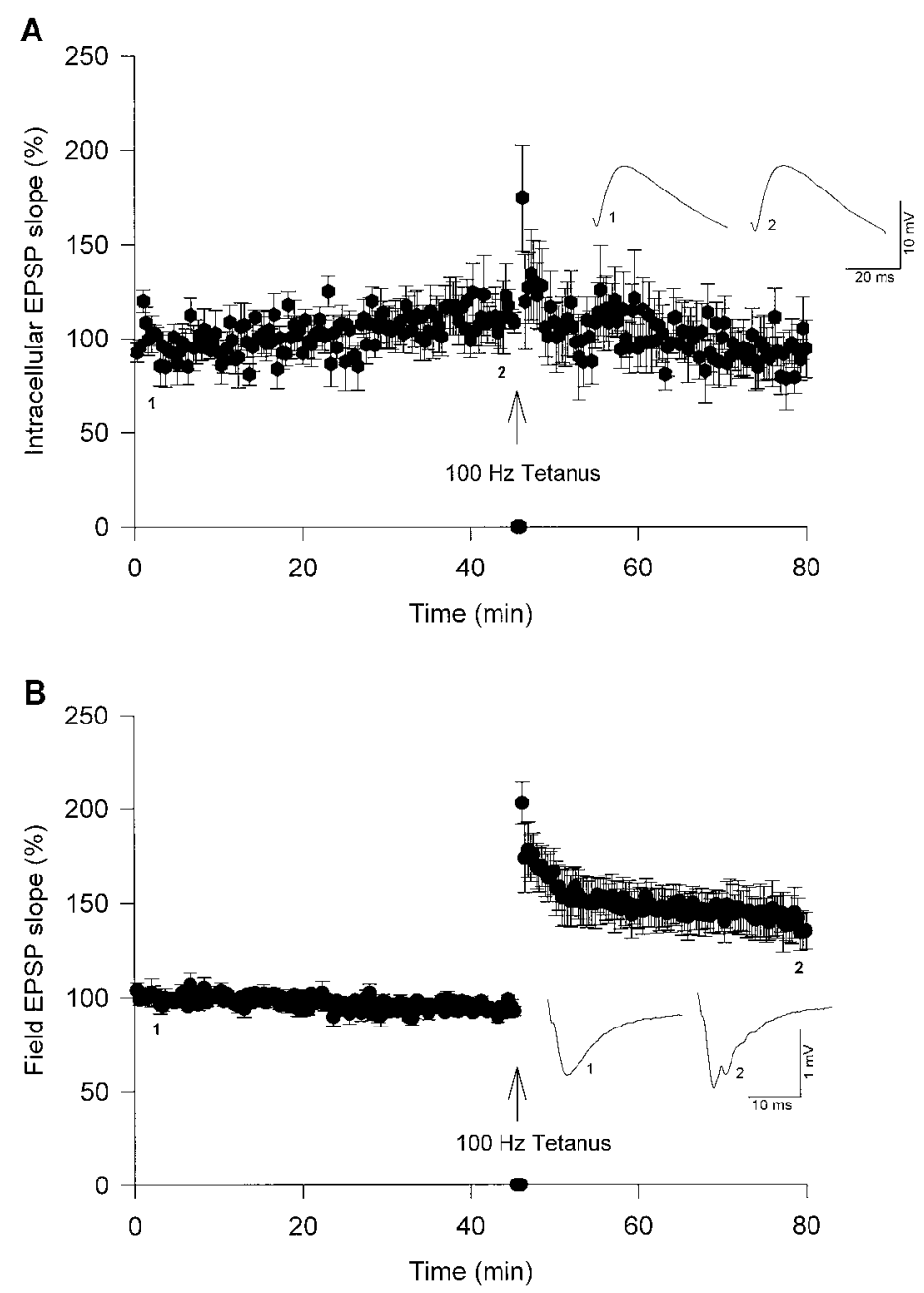
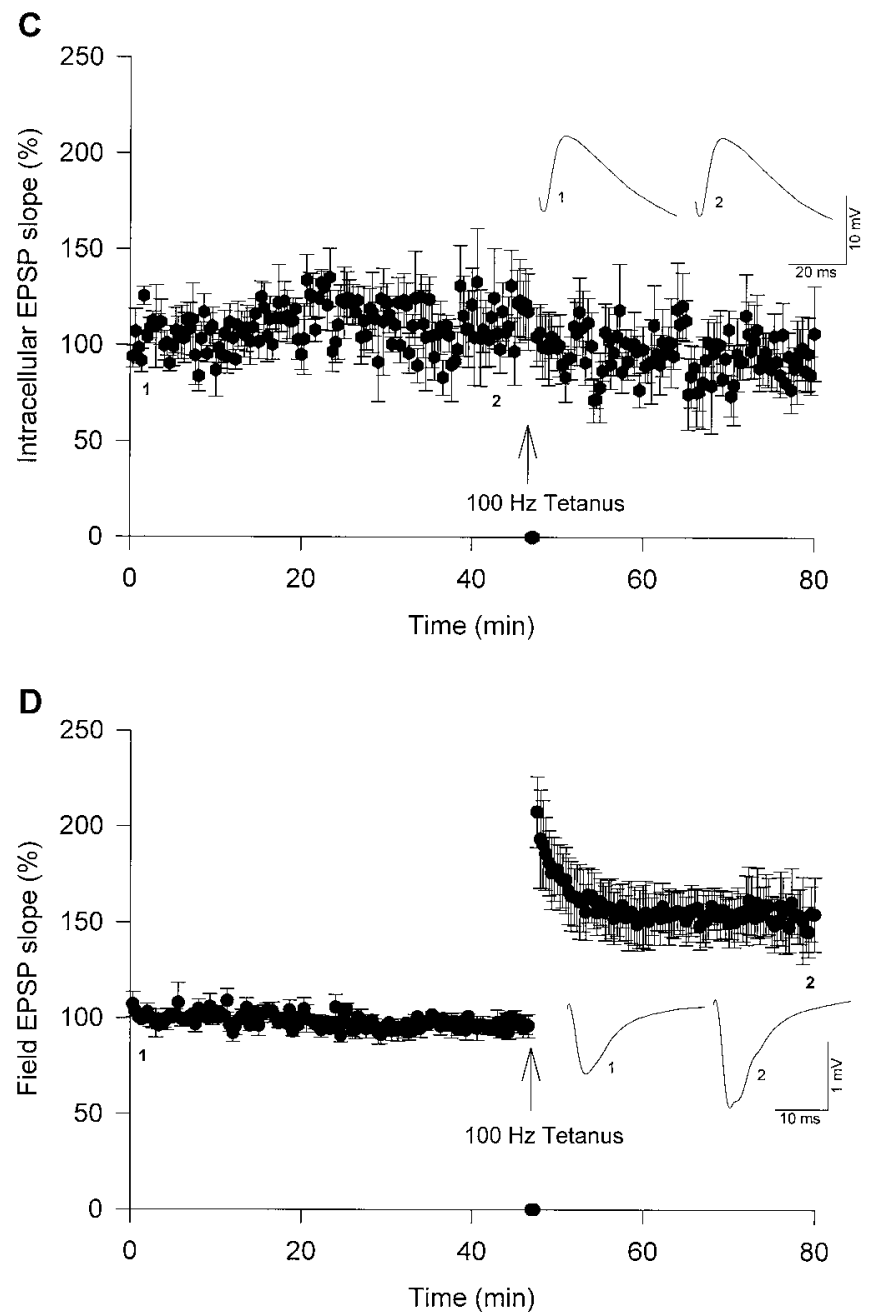

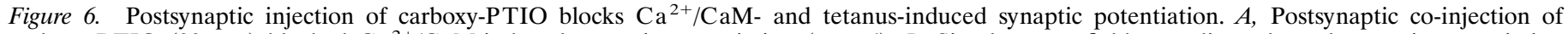

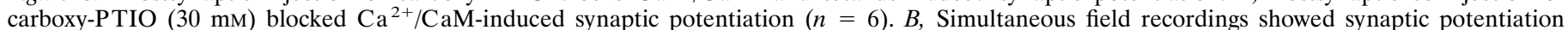

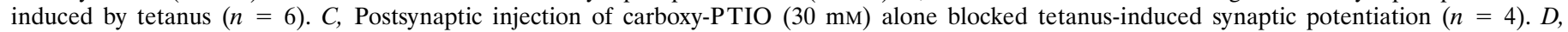
Simultaneous field recordings showed synaptic potentiation induced by tetanus $(n=4)$.

activate NOS to produce NO (Bredt and Snyder, 1990, 1994; Bredt et al., 1992; Brenman et al., 1996), which may act like a retrograde messenger that contributes to PPF attenuation. NO is believed to function as an intercellular (retrograde) messenger in synaptic potentiation induced by tetanus or pairing protocols (O’Dell et al., 1991; Schuman and Madison, 1991, 1994a; Haley et al., 1992; Grathwaite and Boulton, 1995; Arancio et al., 1996; Malen and Chapman, 1997) (but see Chetkovitch et al., 1993; Williams et al., 1993a; Cummings et al., 1994).

Our results show that $\mathrm{Ca}^{2+} / \mathrm{CaM}$-induced potentiation can be blocked by the NOS inhibitor L-NAME through either extracellular perfusion or postsynaptic co-injection with $\mathrm{Ca}^{2+} / \mathrm{CaM}$. Thus, synaptic potentiation induced by postsynaptic injection of $\mathrm{Ca}^{2+} / \mathrm{CaM}$ is NOS-dependent. To our surprise, extracellular perfusion of membrane-impermeable NO scavengers MGD-Fe and carboxy-PTIO did not decrease $\mathrm{Ca}^{2+} / \mathrm{CaM}$-induced potentiation, even though these NO scavengers strongly attenuated tetanus-induced potentiation. Therefore, NO appears not to be a retrograde messenger in $\mathrm{Ca}^{2+} / \mathrm{CaM}$-induced synaptic potentiation. In contrast, postsynaptic co-injection of carboxy-PTIO with $\mathrm{Ca}^{2+} / \mathrm{CaM}$ blocked $\mathrm{Ca}^{2+} / \mathrm{CaM}$-induced synaptic potentiation. These results suggest that NO produced by the activation of NOS acts locally at a postsynaptic site(s) and is required during $\mathrm{Ca}^{2+} /$ CaM-induced synaptic potentiation.

Previous results indicate that NO might act at postsynaptic sites. First, NO-related species modulate NMDA receptor function by modulating its redox status and thereby decreasing $\mathrm{Ca}^{2+}$ influx (Lei et al., 1992; Lipton et al., 1993; Lipton and Wang, 1996; Lipton et al., 1996). In addition, $\mathrm{Ca}^{2+} / \mathrm{CaM}$ can bind to NMDA receptors and reduce channel open probability (Ehlers et al., 1996). Thus, the dual actions of $\mathrm{NO}$ and $\mathrm{Ca}^{2+} / \mathrm{CaM}$ on reducing NMDA-mediated $\mathrm{Ca}^{2+}$ influx could occur during $\mathrm{Ca}^{2+} / \mathrm{CaM}$-induced synaptic potentiation, suggesting that increased $\mathrm{Ca}^{2+}$ influx via NMDA receptors may not be important for this synaptic plasticity. Second, $\mathrm{NO}$ enhances $\mathrm{Ca}^{2+} / \mathrm{CaM}-$ dependent phosphorylation of proteins in isolated postsynaptic density (PSD) fractions (Wu et al., 1996). The NO-stimulated enhancement of $\mathrm{Ca}^{2+} / \mathrm{CaM}$-dependent phosphorylation in PSDs may be important during $\mathrm{Ca}^{2+} / \mathrm{CaM}$-induced synaptic potentiation. Both CaMKII and AMPA receptors are present in hippocampal PSDs (Kelly et al., 1984, 1985; Riquelme et al., 1993; Rao et al., 1998). The apparent phosphorylation of AMPA receptors by CaMKII is enhanced during LTP (Barria et al., 1997), and this phosphorylation increases AMPA receptor conductance 
(Derkach et al., 1998). Therefore, NO might increase the phosphorylation and conductance of AMPA receptors by CaMKII during $\mathrm{Ca}^{2+} / \mathrm{CaM}$-induced potentiation. Third, NO oxidizes neurogranin/RC3 (Mahoney et al., 1996; Sheu et al., 1996; Li et al., 1999). Neurogranin is a postsynaptic PKC substrate, which binds calmodulin in the absence of $\mathrm{Ca}^{2+}$ (Baudier et al., 1991; Huang et al., 1993; Gerendasy et al., 1995; Sato et al., 1995). Compared with reduced neurogranin, oxidized neurogranin binds CaM with lower affinity and is a poorer substrate for PKC (Mahoney et al., 1996; Sheu et al., 1996; Li et al., 1999). Thus, if neurogranin undergoes substantial NO-dependent oxidation during postsynaptic injections of $\mathrm{Ca}^{2+} / \mathrm{CaM}$, then more $\mathrm{CaM}$ and PKC could be available to enhance synaptic transmission.

Postsynaptic NO may activate additional signaling pathways, which could contribute to $\mathrm{Ca}^{2+} / \mathrm{CaM}$-induced synaptic potentiation. NO activates soluble guanylyl cyclase, which produces cGMP that then activates protein kinase G (PKG) (Garthwaite and Boulton, 1995). In rat hippocampus, the expression of guanylyl cyclase and CaM mRNAs are high in pyramidal neurons and dentate granule cells (Matsuoka et al., 1992). Thus, postsynaptic injections of $\mathrm{Ca}^{2+} / \mathrm{CaM}$ could activate NOS and produce NO, which then stimulates guanylyl cyclase to enhance synaptic transmission through the activation of PKG. Inhibitors of guanylyl cyclase and PKG block the induction of LTP (Zhou et al., 1994a; Boulton et al., 1995), whereas cGMP analogs that activate PKG lower the threshold of LTP induction (Zhou et al., 1994b; Arancio et al., 1995). However, there is evidence that does not support a role of NO-cGMP-PKG pathways in synaptic potentiaton (Schuman et al., 1994; Selig et al., 1996; Wu et al., 1998; Kleppisch et al., 1999). Moreover, LTP is normal in mice lacking PKG-I and/or PKG-II but can be attenuated by an NOS inhibitor (Kleppisch et al., 1999). Thus, understanding the involvement of NO-cGMP-PKG signaling pathways in LTP and/or $\mathrm{Ca}^{2+} / \mathrm{CaM}-$ induced potentiation awaits further investigation.

Another potential target for $\mathrm{NO}$ is ADP-ribosyltransferase (ADPRT; Schuman et al., 1994; Willmott et al., 1996). Extracellular application of ADPRT inhibitors block tetanus-induced potentiation (Schuman et al., 1994). Mice lacking PKG-I and/or -II display normal tetanus-LTP, but LTP is blocked by an ADPRT inhibitor (Kleppisch et al., 1999). NO can indirectly activate ADP-ribose cyclase to produce cyclic ADP-ribose (Willmott et al., 1996), which can enhance $\mathrm{Ca}^{2+}$ release from intracellular ryanodine-sensitive $\mathrm{Ca}^{2+}$ stores (Willmott et al., 1996). Calcium release from ryanodine-sensitive $\mathrm{Ca}^{2+}$ stores has been shown to contribute to tetanus-LTP in hippocampal slices (Obenaus et al., 1989; Wang et al., 1996; Wang and Kelly, 1997a). An additional intracellular target for NO is p2 $1^{\text {ras }}$ (Ras) (Yun et al., 1998). NO can activate immunoprecipitated neuronal Ras (Yun et al., 1998). Ras activation leads to phosphorylation and activation of mitogen-activated protein kinases (MAPKs), which regulate gene transcription and modulate long-term synaptic plasticity (Thomas et al., 1992; Wood et al., 1992; Moodie et al., 1993; Williams et al., 1993b; Yun et al., 1998). MAPKs are also involved in LTP induction in the hippocampal CA1 region (English and Sweatt, 1996, 1997). In summary, the ability of NO to modulate these additional pathways could contribute to $\mathrm{Ca}^{2+} / \mathrm{CaM}$ induced synaptic potentiation (Wang and Kelly, 1995).

Postsynaptic injections of $\mathrm{Ca}^{2+} / \mathrm{CaM}$ (Wang and Kelly, 1995) or CaMKII (Lledo et al., 1995) induce synaptic potentiation. In both cases, potentiation induced by these postsynaptic manipulations occludes tetanus-LTP and vice versa (Lledo et al., 1995; Wang and Kelly, 1995, 1996). The expression of a constitutively active recombinant $\mathrm{CaMKII}$ in CA1 neurons potentiated synaptic transmission, which occluded tetanus-LTP (Pettit et al., 1994). Mutation studies with mice lacking $\alpha$-CaMKII, or expressing an altered autophosphorylation phenotype of $\alpha$-CaMKII indicated that CaMKII is required for tetanus-LTP (Silva et al., 1992; Giese et al., 1998). $\mathrm{Ca}^{2+} / \mathrm{CaM}$-induced potentiation and tetanusLTP require postsynaptic $\mathrm{Ca}^{2+} / \mathrm{CaM}$-dependent protein kinase activities (Malenka et al., 1989; Malinow et al., 1989; Malinow and Tsien, 1990b; Lledo et al., 1995; Wang and Kelly, 1995). Thus, $\mathrm{Ca}^{2+} / \mathrm{CaM}-$ and CaMKII-induced potentiation share common mechanisms with tetanus-LTP (Lledo et al., 1995; Wang and Kelly, 1995).

Here we report that even though both $\mathrm{Ca}^{2+} / \mathrm{CaM}$-induced potentiation and tetanus-LTP are NO-dependent, they are not the same. NO appears to function primarily as a retrograde messenger in LTP, because NOS inhibitors and extracellular NO scavengers block tetanus- or pairing-induced synaptic potentiation (O'Dell et al., 1991, 1994; Schuman and Madison, 1991, 1994a; Haley et al., 1992; Hawkins et al., 1994; Garthwaite and Boulton, 1995; Arancio et al., 1996; Malen and Chapman, 1997). However, these studies indicate that NO may also work at postsynaptic sites, because postsynaptic injections of a NOS inhibitor or NO scavenger blocked tetanus-LTP (Schuman and Madison, 1994a; Arancio et al., 1996). Similar to tetanus-LTP, $\mathrm{Ca}^{2+} / \mathrm{CaM}$-induced potentiation is blocked by extracellular application or postsynaptic co-injection of an NOS inhibitor. In contrast, $\mathrm{Ca}^{2+} / \mathrm{CaM}$-induced potentiation is blocked by postsynaptic co-injection of an NO scavenger, but not by extracellular applications of NO scavengers. Thus, we believe that NO acts at a postsynaptic site(s) during $\mathrm{Ca}^{2+} / \mathrm{CaM}$-induced potentiation. It is possible that during high-frequency stimulation or pairing protocols, presynaptic as well as postsynaptic components are activated through a variety of signal transduction cascades, so NO could react with its targets at both presynaptic and postsynaptic sites. Potentiation induced by injecting $\mathrm{Ca}^{2+} / \mathrm{CaM}$ might activate postsynaptic NO targets without activating presynaptic targets. In conclusion, NO serves as a postsynaptic intracellular signaling molecule but not a retrograde messenger during $\mathrm{Ca}^{2+} / \mathrm{CaM}-$ induced potentiation.

\section{REFERENCES}

Amano F, Noda T (1995) Improved detection of nitric oxide radical (NO) production in an activated macrophage culture with a radical scavenger, carboxy-PTIO and Griess reagent. FEBS Lett 368:425-428.

Arancio O, Kandel ER, Hawkins RD (1995) Activity-dependent longterm enhancement of transmitter release by presynaptic $3^{\prime}-5^{\prime}$-cyclic GMP in cultured hippocampal neurons. Nature 376:74-80.

Arancio O, Kiebler M, Lee C, Lev-Ram V, Tsien R, Kandel E, Hawkins R (1996) Nitric oxide acts directly in the presynaptic neuron to produce long-term potentiation in cultured hippocampal neurons. Cell 87:1025-1035.

Az-ma T, Fujii K, Yuge O (1994) Reaction between imidazolineoxil $\mathrm{N}$-oxide (carboxy-PTIO) and nitric oxide released from cultured endothelial cells: quantitative measurement of nitric oxide by ESR spectrometry. Life Sci 54:PL185-PL190.

Barria A, Muller D, Griffith LC, Soderling TR (1997) Phosphorylation of AMPA-type glutamate receptors by $\mathrm{Ca}^{2+} /$ calmodulin-dependent protein kinase II during long-term potentiation. Science 276:2042-2045.

Baudier J, Deloulme JC, Van Dorsselear A, Black D, Matthes HWD (1991) Purification and characterization of a brain-specific protein kinase C substrate, neurogranin (p 17). J Biol Chem 266:229-237.

Bliss TVP, Collingridge GL (1993) A synaptic model of memory: LTP in the hippocampus. Nature 361:31-39.

Bolshakov VY, Siegelbaum SA (1995) Regulation of hippocampal trans- 
mitter release during development and long-term potentiation. Science 269:1730-1734.

Boulton C, Southam E, Garthwaite J (1995) Nitric oxide-dependent long-term potentiation is blocked by a specific inhibitor of soluble guanylyl cyclase. Neuroscience 69:699-703.

Braun AP, Shulman H (1995) The multifunctional calcium/calmodulindependent protein kinase: from form to function. Annu Rev Physiol 57:417-445.

Bredt D, Snyder S (1994) Nitric oxide: a physiologic messenger molecule. Annu Rev Biochem 63:175-195.

Bredt DS, Snyder SH (1990) Isolation nitric oxide synthetase, a calmodulin-requiring enzyme. Proc Natl Acad Sci USA 87:682-685.

Bredt DS, Ferris CD, Snyder SH (1992) Nitric oxide synthase regulatory sites. J Biol Chem 267:10976-10981.

Brenman J, Chao D, Gee S, McGee A, Craven S, Santillano D, Wu Z, Huang F, Xia H, Peters M, Froehner S, Bredt D (1996) Interaction of nitric oxide synthase with the postsynaptic density protein PSD-95 and alpha1-syntrophin mediated by PDZ domains. Cell 84:757-767.

Chetkovitch D, Klann E, Sweatt J (1993) Nitric oxide synthaseindependent long-term potentiation in area CA1 of hippocampus. NeuroReport 4:919-922.

Creager R, Dunwiddie T, Lynch G (1980) Paired-pulse and frequency facilitation in the CA1 region of the in vitro rat hippocampus. J Physiol (Lond) 299:409-424.

Cummings J, Nicola S, Malenka R (1994) Induction in the rat hippocampus of long-term potentiation and long-term depression in the presence of a nitric oxide synthase inhibitor. Neurosci Lett 176:110-114.

Derkach V, Barria A, Soderling TR (1998) CaM-KII increases single channel conductance of recombinant AMPA glutamate receptor. Soc Neurosci Abstr 24:1826.

Dinerman JL, Dawson TM, Schell MJ, Snowman A, Snyder SH (1994) Endothelial nitric oxide synthase localized to hippocampal pyramidal cells: implication for synaptic plasticity. Proc Natl Acad Sci USA 91:4214-4218.

Doyle C, Slater P (1997) Localization of neuronal and endothelial nitric oxide synthase isoforms in human hippocampus. Neuroscience 76:387-395.

Ehlers M, Zhang S, Bernhardt J, Huganir R (1996) Inactivation of NMDA receptors by direct interaction of calmodulin with the NR1 subunit. Cell 84:745-755.

Eliasson MJ, Blackshaw S, Schell MJ, Snyder SH (1997) Neuronal nitric oxide synthase alternatively spliced forms: prominent functional localizations in the brain. Proc Natl Acad Sci USA 94:3396-3401.

English JD, Sweatt JD (1996) Activation of p42 mitogen-activated protein kinase in hippocampal long term potentiation. J Biol Chem 271:24329-24332.

English JD, Sweatt JD (1997) A requirement for the mitogen-activated protein kinase cascade in hippocampal long term potentiation. J Biol Chem 272:19103-19106.

Garthwaite J, Boulton C (1995) Nitric oxide signaling in the central nervous system. Annu Rev Physiol 57:683-706.

Gerendasy DD, Herron SR, Jennings PA, Sutcliffe JG (1995) Calmodulin stabilizes an amphiphilic alpha-helix within RC3/neurogranin and GAP-43/neuromodulin only when $\mathrm{Ca}^{2+}$ is absent. J Biol Chem 270:6741-6750.

Giese KP, Fedorov NB, Filipkowski RK, Silva AJ (1998) Autophosphorylation at $\mathrm{Thr}^{286}$ of the alpha calcium-calmodulin kinase II in LTP and learning. Science 279:870-873.

Guerini D (1997) Calcineurin: not just a simple protein phosphatase. Biochem Biophys Res Commun 235:271-275.

Guerrini R, Menegazzi P, Anacardio R, Marastoni M, Tomatis R, Zorzato F, Treves S (1995) Calmodulin binding sites of the skeletal, cardiac, and brain ryanodine receptor $\mathrm{Ca}^{2+}$ channels: modulation by the catalytic subunit of cAMP-dependent protein kinase? Biochemistry 34:5120-5129.

Haley J, Wilcox G, Chapman P (1992) The role of nitric oxide in hippocampal long-term potentiation. Neuron 8:211-216.

Hawkins RD, Zhuo M, Arancio O (1994) Nitric oxide and carbon monoxide as possible retrograde messengers in hippocampal long-term potentiation. J Neurobiol 25:652-665.

Hisatsune C, Umemori H, Inoue T, Michikawa T, Kohda K, Mikoshiba K, Yamamoto T (1997) Phosphorylation-dependent regulation of $\mathrm{N}$-methyl-D-aspartate receptors by calmodulin. J Biol Chem 272:20805-20810.

Hogg N, Singh R, Joseph J, Neese F, Kalyanaraman B (1995a) Reactions of nitric oxide with nitronyl nitroxides and oxygen: prediction of nitrite and nitrate formation by kinetic simulation. Free Radic Res 22:47-56.

Hogg N, Struck A, Goss S, Santanam N, Joseph J, Parthasarathy S, Kalyanaraman B (1995b) Inhibition of macrophage-dependent low density lipoprotein oxidation by nitric oxide donors. J Lipid Res 36:1756-1762.

Huang K-P, Huang FL, Chen H-C (1993) Characterization of a 7.5-kDa protein kinase $\mathrm{C}$ substrate ( $\mathrm{RC} 3$ protein, neurogranin) from rat brain. Arch Biochem Biophys 305:570-580.

Ikemoto T, Iino M, Endo M (1995) Enhancing effect of calmodulin on $\mathrm{Ca}^{2+}$-induced $\mathrm{Ca}^{2+}$ release in the sarcoplasmic reticulum of rabbit skeletal muscle fibres. J Physiol (Lond) 487:573-582.

Kelly PT, McGuinness TL, Greengard P (1984) Evidence that the major postsynaptic density protein is a component of a $\mathrm{Ca}^{2+} /$ calmodulindependent protein kinase. Proc Natl Acad Sci USA 81:945-949.

Kelly PT, Yip RK, Shields SM, Hay M (1985) Calmodulin-dependent protein phosphorylation in synaptic junctions. J Neurochem 45:1620-1634.

Klee CB, Ren H, Wang X (1998) Regulation of the calmodulinstimulated protein phosphatase, calcineurin. $J$ Biol Chem 273:13367-13370.

Kleppisch T, Pfeifer A, Klatt P, Ruth P, Montkowski A, Fassler R, Hofmann F (1999) Long-term potentiation in the hippocampal CA1 region of mice lacking cGMP-dependent kinases is normal and susceptible to inhibition of nitric oxide synthase. J Neurosci 19:48-55.

Ko G, Kelly P (1998) A role of nitric oxide synthase in $\mathrm{Ca}^{2+}$ / calmodulin-induced synaptic potentiation in hippocampal CA1 neurons. Soc Neurosci Abstr 24:1074.

Komarov A, Lai C (1995) Detection of nitric oxide production in mice by spin-trapping electron paramagnetic resonance spectroscopy. Biochim Biophys Acta 1272:29-36.

Komarov A, Maattson D, Jones M, Singh P, Lai C (1993) In vivo spin trapping of nitric oxide in mice. Biochem Biophys Res Commun 195:1191-1198.

Kotake Y (1996) Continuous and quantitative monitoring of rate of cellular nitric oxide generation. Methods Enzymol 268:222-229.

Kotake Y, Tanigawa T, Tanigawa M, Ueno I (1995) Spin trapping isotopically-labelled nitric oxide produced from $\left[{ }^{15} \mathrm{~N}\right] \mathrm{L}$-arginine and $\left[{ }^{17} \mathrm{O}\right.$ ]dioxygen by activated macrophages using a water soluble $\mathrm{Fe}$ ${ }^{2+}$-dithiocarbamate spin trap. Free Radic Res 23:287-295.

Kotake Y, Tanigawa T, Tanigawa M, Ueno I, Allen D, Lai C (1996) Continuous monitoring of cellular nitric oxide generation by spin trapping with an iron-dithiocarbamate complex. Biochim Biophys Acta 1289:362-368.

Lai C, Komarov A (1994) Spin trapping of nitric oxide produced in vivo in septic-shock mice. FEBS Lett 345:120-124.

Lee S-J, Stull JT (1998) Calmodulin-dependent regulation of inducible and neuronal nitric oxide synthase. J Biol Chem 273:27430-27437.

Lei SZ, Pan Z-H, Aggarwal SK, Chen H-S, Hartman J, Sucher NJ, Lipton SA (1992) Effect of nitric oxide production on the redox modulatory site of the NMDA receptor-channel complex. Neuron 8:1087-1099.

Li J, Pak J, Huang F, Huang K-P (1999) N-Methyl-D-aspartate induces neurogranin/RC3 oxidation in rat brain slices. J Biol Chem 274:1294-1300.

Lipton SA, Wang YF (1996) NO-related species can protect from focal cerebral ischemia/reperfusion. In: Pharmacology of cerebral ischemia 1996 (Krieglstein J, ed), pp 183-191. Stuttgart: Medpharm Scientific.

Lipton SA, Choi Y-B, Pan Z-H, Lei SZ, Chen H-S, Sucher NJ, Loscalzo J, Singel DJ, Stamler JS (1993) A redox-based mechanism for the neuroprotective and neurodestructive effects of nitric oxide and related nitroso-compounds. Nature 364:626-632.

Lipton SA, Choi Y-B, Sucher NJ, Pan Z-H, Stamier JS (1996) Redox state, NMDA receptors and NO-related species. Trends Pharmacol 17:186-187.

Lledo PM, Hjelmstad GO, Mukherji S, Soderling TR, Malenka RC, Nicoll RA (1995) Calcium/calmodulin-dependent kinase II and longterm potentiation enhance synaptic transmission by the same mechanism. Proc Natl Acad Sci USA 92:11175-11179.

Maeda H, Akaike T, Yoshida M, Suga M (1994) Multiple functions of nitric oxide in pathophysiology and microbiology: analysis by a new nitric oxide scavenger. J Leukocyte Biol 56:588-592.

Magleby KL (1987) Short-term changes in synaptic efficacy. In: Synaptic 
function (Edelman GM, Gall WE, Cowan WM, eds), pp 21-57, New York: Wiley.

Mahoney C, Pak J, Huang K-P (1996) Nitric oxide modification of rat brain neurogranin. J Biol Chem 46:28798-28804.

Malen P, Chapman P (1997) Nitric oxide facilitates long-term potentiation, but not long-term depression. J Neurosci 17:2645-2651.

Malenka RC, Kauer JA, Perkel DJ, Mauk MD, Kelly PT, Nicoll RA, Waxham MN (1989) An essential role for postsynaptic calmodulin and protein kinase activity in long-term potentiation. Nature 340:554-557.

Malinow R, Tsien RW (1990a) Presynaptic enhancement shown by whole-cell recordings of long-term potentiation in hippocampal slices. Nature 346:177-180.

Malinow R, Tsien RW (1990b) Identifying and localizing protein kinases necessary for LTP. Adv Exp Med Biol 268:301-305.

Malinow R, Schulman H, Tsien RW (1989) Inhibition of postsynaptic PKC or CaM KII blocks induction but not expression of LTP. Science 245:862-866.

Manabe T, Wyllie DJA, Perkel DJ, Nicoll RA (1993) Modulation of synaptic transmission and long-term potentiation: effect on pairedpulse facilitation and EPSC variance in the CA1 region of the hippocampus. J Neurophysiol 70:1451-1459.

Matsuoka I, Giuili G, Poyard M, Stengel D, Parma J, Guellaen G, Hanoune J (1992) Localization of adenylyl and guanylyl cyclase in rat brain by in situ hybridization: comparison with calmodulin mRNA distribution. J Neurosci 12:3350-3360.

Molday RS (1996) Calmodulin regulation of cyclic-nucleotide-gated channels. Curr Opin Neurobiol 6:445-452.

Moodie SA, Willumsen BM, Weber MJ, Wolfman A (1993) Complexes of ras.GTP with raf-1 and mitogen-activated protein kinase kinase. Science 260:1658-1661.

Muller D, Lynch G (1989) Evidence that changes in presynaptic calcium currents are not responsible for long-term potentiation in hippocampus. Brain Res 479:290-299.

Nicolarakis PJ, Lin YQ, Bennett MR (1994) Effect of nitric oxide synthase inhibition on long-term potentiation at associational-commissural and mossy fibre synapses on CA3 pyramidal neurones. Br J Pharmacol 111:521-524.

Obenaus A, Mody I, Baimbridge KG (1989) Dantrolene-Na (Dantrium) blocks induction of long-term potentiation in hippocampal slices. Neurosci Lett 98:172-178.

Ocorr KA, Schulman H (1991) Activation of multifunctional $\mathrm{Ca}^{++} /$ calmodulin-dependent kinase in intact hippocampal slices. Neuron 6:907-914.

O'Dell TJ, Hawkins RD, Kandel ER, Arancio O (1991) Tests of the roles of two diffusible substances in long-term potentiation: evidence for nitric oxide as a possible early retrograde messenger. Proc Natl Acad Sci USA 88:11285-11289.

O'Dell TJ, Huang PL, Dawson TM, Dinerman JL, Snyder SH, Kandel ER, Fishman MC (1994) Endothelial NOS and the blockade of LTP by NOS inhibitors in mice lacking neuronal NOS. Science 265:542-546.

Pettit DL, Periman R, Malinow R (1994) Potentiated transmission and prevention of further LTP by increased CaMKII activity in postsynaptic hippocampal slice neurons. Science 266:1881-1885.

Pieper G, Lai C (1996) Evaluation of vascular actions of the nitric oxide-trapping agent, $N$-methyl-D-glucamine dithiocarbamate-Fe ${ }^{2+}$, on basal and agonist-stimulated nitric oxide activity. Biochem Biophys Res Commun 219:584-590.

Rao A, Kim E, Sheng M, Craig AM (1998) Heterogeneity in the molecular composition of excitatory postsynaptic sites during development of hippocampal neurons in culture. J Neurosci 18:1217-1229.

Rhoads A, Friedberg F (1997) Sequence motifs for calmodulin recognition. FASEB J 11:331-340.

Riquelme G, Wyneken U, Villanueva S, Orrego F (1993) Recordings of glutamate receptor channels in isolated postsynaptic densities. NeuroReport 4:1163-1166.

Sato T, Xiao D-M, Li H, Huang FL, Huang K-P (1995) Structure and regulation of the gene encoding the neuron-specific protein kinase $\mathrm{C}$ substrate neurogranin (RC3 protein). J Biol Chem 270:10314-10322.

Schulz PE, Cook EP, Johnston D (1994) Changes in paired-pulse facilitation suggest presynaptic involvement in long-term potentiation. J Neurosci 14:5325-5337.
Schuman E, Madison D (1994a) Locally distributed synaptic potentiation in the hippocampus. Science 263:532-36.

Schuman E, Madison D (1994b) Nitric oxide and synaptic function. Annu Rev Neurosci 17:153-183.

Schuman E, Meffert M, Schulman H, Madison D (1994) An ADPribosyltransferase as a potential target for nitric oxide action in hippocampal long-term potentiation. Proc Natl Acad Sci USA 91:11958-11962.

Schuman EM, Madison DV (1991) A requirement for the intercellular messenger nitric oxide in long-term potentiation. Science 254:1503-1506.

Selig DK, Segal MR, Liao D, Malenka RC, Malinow R, Nicoll RA, Lisman JE (1996) Examination of the role of cGMP in long-term potentiation in the CA1 region of the hippocampus. Learn Mem 3:42-48.

Sharma RK (1995) Signal transduction: regulation of cAMP concentration in cardiac muscle by calmodulin-dependent cyclic nucleotide phosphodiesterase. Mol Cell Biochem 149-150:241-247.

Sheu F-S, Mahoney C, Seki K, Huang K-P (1996) Nitric oxide modification of rat brain neurogranin affects its phosphorylation by protein kinase C and affinity for calmodulin. J Biol Chem 271:22407-22413.

Silva AJ, Stevens CF, Tonegawa S, Wang Y (1992) Deficient hippocampal long-term potentiation in alpha-calcium-calmodulin kinase II mutant mice. Science 257:201-206.

Smit MJ, Iyengar R (1998) Mammalian adenylyl cyclases. Adv Second Messenger Phosphoprotein Res 32:1-21.

Son H, Hawkins R, Martin K, Kiebler M, Huang P, Fishman M, Kandel E (1996) Long-term potentiation is reduced in mice that are doubly mutant in endothelial and neuronal nitric oxide synthase. Cell 87:1015-1023.

Sunahara RK, Dessauer CW, Gilman AG (1996) Complexity and diversity of mammalian adenylyl cyclases. Annu Rev Pharmacol Toxicol 36:461-480.

Thomas SM, DeMarco M, D’Arcangelo G, Halegoua S, Brugge JS (1992) Ras is essential for nerve-growth factor- and phorbol ester- induced tyrosine phosphorylation of MAP kinase. Cell 68:1031-1040.

Wang JH, Kelly PT (1995) Postsynaptic injection of $\mathrm{Ca}^{2+} / \mathrm{CaM}$ induces synaptic potentiation requiring CaM-KII and PKC activity. Neuron 15:443-452.

Wang J-H, Kelly P (1996) Regulation of synaptic facilitation by postsynaptic $\mathrm{Ca}^{2+} / \mathrm{CaM}$ pathways in hippocampal CA1 neurons. J Neurophysiol 76:276-286.

Wang J-H, Kelly P (1997a) Developmental changes of postsynaptic calcineurin and $\mathrm{IP}_{3}$ receptors regulating synaptic transmission. Soc Neurosci Abstr 23:1128.

Wang J-H, Kelly PT (1997b) Attenuation of paired-pulse facilitation associated with synaptic potentiation mediated by postsynaptic mechanisms. J Neurophysiol 78:2707-2716.

Wang Y, Wu J, Rowan MJ, Anwyl R (1996) Ryanodine produces a low frequency stimulation-induced NMDA receptor-independent longterm potentiation in the rat dentate gyrus in vitro. J Physiol (Lond) 495.3:755-767.

Williams JH, Li Y-G, Nayak A, Errington ML, Murphy KPSJ, Bliss TVP (1993a) The suppression of long-term potentiation in rat hippocampus by inhibitors of nitric oxide synthase is temperature and age dependent. Neuron 11:877-884.

Williams MG, Paradis H, Agarwal S, Charest DL, Pelech SL, Roberts TM (1993b) Raf-1 and p21 $1^{\text {v-ras }}$ cooperate in the activation of mitogenactivated protein kinase. Proc Natl Acad Sci USA 90:5772-5776.

Willmott N, Sethi JK, Walseth TF, Lee HC, White AM, Galione A (1996) Nitric oxide-induced mobilization of intracellular calcium via the cyclic ADP-ribose signaling pathway. J Biol Chem 271:3699-3705.

Wood KW, Sarneck C, Roberts TM, Blenis J (1992) Ras mediates nerve growth factor receptor modulation of three signal-transducing protein kinases: MAP kinase, raf-1 and RSK. Cell 68:1041-1050.

Wu J, Wang Y, Rowan M, Anwyl R (1998) Evidence for involvement of the cGMP-protein kinase G signaling system in the induction of longterm depression, but not long-term potentiation, in the dentate gyrus in vitro. J Neurosci 18:3589-3596.

Wu K, Xu J, Suen P, Huang Y, Mount HTJ (1996) Nitric oxide increases calcium/calmodulin-dependent phosphorylation of proteins in the postsynaptic density of adult rat cerebral cortex. Mol Brain Res 40:22-26. Yip S, Ip J, Sastry B (1996) Electrophysiological actions of hemoglobin 
on rat hippocampal CA1 pyramidal neurons. Brain Res 713:134-142.

Yoshida M, Akaike T, Wada Y, Sato K, Ikeda K, Ueda S, Maeda H (1994) Therapeutic effects of imidazolineoxyl $\mathrm{N}$-oxide against endotoxin shock through its direct nitric oxide-scavenging activity. Biochem Biophys Res Commun 202:923-930.

Yun H-Y, Gonzalez-Zulueta M, Dawson VL, Dawson TM (1998) Nitric oxide mediates $N$-methyl-D-aspartate receptor-induced activation of

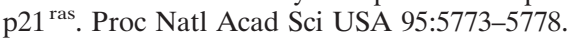

Zagotta W, Siegelbaum S (1996) Structure and function of cyclic nucleotide-gated channels. Annu Rev Neurosci 19:235-263.

Zhang S, Ehler M, Bernhardt J, Su C, Huganir R (1998) Calmodulin mediates calcium-dependent inactivation of $N$-methyl-D-aspartate receptors. Neuron 21:443-453.
Zhao AZ, Yan C, Sonnenburg WK, Beavo JA (1997) Recent advances in the study of $\mathrm{Ca}^{2+} / \mathrm{CaM}$-activated phosphodiesterases: expression and physiological functions. Adv Second Messenger Phosphoprotein Res 31:237-251.

Zhou M, Hu Y, Schultz C, Kandel E, Hawkins R (1994a) Role of guanylyl cyclase and cGMP-dependent protein kinase in long-term potentiation. Nature 368:635-639.

Zhou M, Kandel E, Hawkins R (1994b) Nitric oxide and cGMP can produce either synaptic depression or potentiation depending on the frequency of presynaptic stimulation in the hippocampus. NeuroReport 5:1033-1036.

Zucker RS (1989) Short-term synaptic plasticity. Annu Rev Neurosci 12:13-31. 